\title{
PENGARUH SINDROMA DEPRESI TERHADAP DISFUNGSI EREKSI
}

\author{
Andre M. P. Hutagalung \\ Christoffel Elim \\ Herdy Munayang
}

\section{Bagian Ilmu Kedokteran Jiwa Fakultas Kedokteran Universitas Sam Ratulangi Manado}

\begin{abstract}
Normal sexual function is a bio-psycho-social process which is significantly related to the quality of life (QOL). Any disturbance in one of the components can be a disaster in sexual life. Erectile dysfunction is a disability to get an erection or to maintain the erection well enough for a sexual intercourse, which persists or recurs at least three months consecutively due to either psychogenic or organic disturbances, or both. Some psychogenic disturbances especially depression, anxiety, and relational distress, play some important roles in ED. Besides that, aging, low testoteron level, physical diseases, and some certain medicines have to be included.
\end{abstract}

Keywords: erection, erectile dysfunction, sexual stimulus, depression

\begin{abstract}
Fungsi seksual yang normal merupakan suatu proses biopsikososial yang berkaitan langsung dengan kualitas hidup. Adanya gangguan pada salah satu komponen dapat menjadi malapetaka bagi kehidupan seksual. Disfungsi ereksi dapat dedefinisikan sebagai suatu ketidakmampuan untuk ereksi atau mempertahankan ereksi yang cukup untuk melakukan hubungan seksual yang memuaskan, yang menetap atau berulang paling tidak selama tiga bulan berturut-turut. Gangguan psikogenik khususnya sindroma depresi, ankietas, dan distres relasional berperan penting dalam hal terjadinya disfungsi ereksi. Disamping itu usia lanjut, rendahnya kadar testoteron, penyakit fisik, dan beberapa jenis obat perlu diperhitungkan.
\end{abstract}

Kata kunci: fisiologi ereksi, disfungsi ereksi, stimulus seksual, depresi

Disfungsi ereksi ialah suatu keadaan di mana ereksi penis tidak dapat dicapai atau dipertahankan untuk melakukan hubungan seksual. Kondisi ini dahulu dikenal dengan istilah impotensi seksual, yang sebenarnya merujuk pada berbagai masalah seksual yang berkaitan dengan gangguan pada libido, gangguan ejakulasi, serta gangguan orgasme.

Disfungsi ereksi dapat diakibatkan oleh karena faktor psikis dan faktor organik. ${ }^{1-3}$ Penyebab-penyebab yang bersifat psikis adalah semua faktor dalam periode kehidupan mulai dari anak hingga usia dewasa. Faktor-faktor dalam kehidupan ini dapat dikelompokkan menjadi faktor predisposisi, faktor presipitasi, dan faktor pembinaan. ${ }^{3}$
Beberapa hal yang tergolong faktor predisposisi adalah pandangan negatif tentang seks, trauma seks, pendidikan tentang seks yang kurang, hubungan keluarga yang terganggu, dan tipe kepribadian. Keadaan yang tergolong dalam faktor presipitasi antara lain adalah akibat psikis karena penyakit atau gangguan fisik, proses penuaan, ketidaksetiaan terhadap pasangan, harapan yang berlebihan, depresi, kecemasan dan kehilangan pasangan atau yang dikenal sebagai widower's syndrome. Sedangkan hal yang tergolong faktor pembinaan adalah pengaruh pengalaman sebelumnya, hilangnya daya tarik pasangan, komunikasi yang tidak baik dan takut yang berkaitan dengan keintiman. ${ }^{3}$ 
Salah satu gangguan jiwa yang sering mengakibatkan disfungsi ereksi adalah sindrom depresi. ${ }^{4}$ Penelitan lain yang dilakukan di Perancis (ELIXIR Study) terhadap 4557 pasien depresi menunjukkan bahwa 78 persen mengalami kehilangan libido 37 persen gangguan ereksi, dan 20 persen mengalami disfungsi orgasme. ${ }^{5}$

Penyebab yang bersumber dari faktor organik dapat dikelompokkan menjadi faktor hormon misalnya kadar hormon prolaktin yang meningkat dan kadar hormon tiroid yang rendah, faktor saraf misalnya gangguan pada faktor saraf parasimpatetik dan bagian otak yang mengontrol sekresi, faktor pembuluh darah arteri misalnya trauma pada pembuluh darah arteri, dan faktor pembuluh darah vena misalnya kerusakan dinding pembuluh darah vena. ${ }^{3}$ Faktor organik lainnya yaitu obat psikotropik, antidepresan, anti-hipertensi, hormon antikolinergik, dan zat-zat psikoaktif lainnya seperti alkohol, amfetamin, nikotin dan kanabis. $^{3}$

Pengobatan terhadap disfungsi ereksi dapat dilakukan melalui 3 tahap, yaitu: 1) Pengobatan lini pertama yaitu sex therapy dan obat-obat erektogenik oral, termasuk di sini adalah yohimbine, apomorfin, Trazodone, I-arginine dan Sildenafil sitrat; 2) Pengobatan lini kedua yaitu penggunaan pompa vakum dan injeksi bahan vasoaktif intraurethral papaverin, pentolamin, protaglandin E1, vasoactive intestinal polipeptide (VIP) dan nitroprusside; dan 3) pengobatan lini ketiga yaitu pemasangan protesis pada korpus kavernosum penis, dan vaso vesektomi. ${ }^{3,6}$

Salah satu penyebab disfungsi ereksi dari faktor psikis adalah sindrom depresi. Sindrom depresi adalah salah satu kumpulan gejala psikiatrik yang ditandai oleh penurunan efek, psikomotor, proses pikir dan gejala-gejala somatik yang menonjol antara lain disfungsi ereksi. Penyebab sindrom depresi dapat bersifat biopsikososial. ${ }^{7-10}$ Untuk menegakkan diagnosis sindrom depresi dapat dilakukan Pedoman Diagnostik Gangguan (sindrom) Depresi menurut Pedoman Penggolongan Diagnosis Gangguan Jiwa di Indonesia Edisi III ${ }^{11}$ dan/atau dengan menggunakan instrumen psikometrik seperti Hamilton Rating Scale for Depression (HRSD). ${ }^{12}$

\section{EREKSI NORMAL}

Ereksi merupakan persyaratan utama bagi pria untuk dapat melakukan hubungan seksual. ${ }^{3}$ Setelah mendapat rangsangan yang cukup melalui berbagai mekanisme maka penis akan mengalami ereksi melalui berbagai tahapan sehingga dapat dipergunakan untuk penetrasi vagina dalam suatu hubungan seksual yang normal.

Demikian pula kemajuan yang dicapai di bidang imunohistokimia juga sangat berperan dalam studi neuroanatomi dan lokasi yang lebih pasti di dalam menentukan lokasi area pada otak yang berperan dalam aktivitas seksual.

Selain itu telah dicapai suatu kemajuan yang pesat pula sering dengan ditemukannya berbagai macam neurotransmiter serta reseptornya yang berkaitan dengan mekanisme ereksi. Pengetahuan tentang neurotransmiter dan reseptornya mempermudah pemahaman tentang gangguan ereksi yang diakibatkan oleh berbagai macam obat.

\section{FISIOLOGI EREKSI}

Fisiologi ereksi sebenarnya sangatlah rumit. Sampai sekarang fisiologi ereksi masih terus berkembang dan terus diteliti. Banyak sekali penemuan baru yang berhubungan dengan jalur kompensasi (compensatory pathways), neurotransmiter maupun enzim kompleks yang terlibat. Secara ringkas mekanisme ereksi menurut berbagai literatur garis besarnya dijelaskan pada pembahasan berikut. ${ }^{3,13-16}$

\section{Stimulus (rangsang) seksual}

Rangsang seksual secara umum dapat berasal dari 2 cara yaitu: rangsang psikis melalui otak (pikiran) dan rangsang fisik atau refleksogenik melalui panca indera.

Rangsang psikis melalui otak (pikiran) terjadi karena ingatan, imaginasi, dan fantasi seksual dengan membayangkan hal-hal yang erotis. Letak pusat rangsang berada di 
daerah hipotalamus dan sistem limbik (girus rektus, bagian medio dorsal dari nukleus thalamus, girus singulat, badan mammilaris, bagian anterior dari talamus dan hipokampus). Stimulus rangsang ini melibatkan saraf panjang simpatis.

Dipihak lain, rangsang fisik dan refleksogenik melalui panca indera dapat timbul melalui beberapa cara yaitu: visual, dengan melihat sesuatu yang erotik; auditorik, mendengar sesuatu yang ditangkap oleh otak sebagai rangsang seksual misalnya desahan erotis; olfaktoris, membaui sesuatu yang membangkitkan gairah taktil, merasakan rabaan yang dirasakan merangsang syahwat. Rabaan ini terasa merangsang terutama pada daerah-daerah sensitif rangsang. Daerah ini adalah bibir, penis, dada, putting, leher, belakang telinga, pusar dan sebagainya. Impuls rangsang ini melibatkan persarafan parasimpatis. Biasanya rangsang seksual itu merupakan campuran antara aktifitas pikiran dan panca indera.

Pusat integrasi dari sistem saraf otonom adalah hipotalamus. Regio medial dan anterior hipotalamus merupakan pusat parasimpatik sedangkan bagian lateral dan posterior merupakan pusat simpatik. Kedua pusat ini mengatur berbagai fungsi fisilogis melalui pusat batang otak (reticular formation). Impuls aferen dari emosi yang menuju pusat di korteks serebri akan melalui dan berkomunikasi dengan hipotalamus. Dengan demikian emosi maupun impuls dari sistem limbik yang berhubungan dengan kehendak (drive) seksual dan tingkah laku juga berhubungan dengan hipotalamus yang akan mengkoordinasi sistem saraf otonom yang terlibat. $^{17}$ Hipotalamus akan bereaksi dengan jalur-jalur otonom yang mengatur pusat kardiovaskuler dan memprojeksikan impuls ke neuron pra ganglionik dari saraf kranial dan corda spinalis. Ekspresinya bisa bersifat simpatik maupun parasimpatik tergantung bagian mana dari hipotalamus yang bereaksi. ${ }^{18}$

Di samping regulasi di hipotalamus ada pula regulasi di kelenjar pineal melalui sinyal dari melatonin sebagian pemberi waktu (zeitgeber atau time giver). ${ }^{19}$ Pada penelitian dan percobaan lain ditemukan kontrol ber- bagai fungsi otonom melalui mekanisme yang disebut biofeedback. ${ }^{18,20}$

Peran psikologi di dalam ereksi didasarkan atas penyesuaian perilaku (behavioal adaptive) pada situasi yang disebut pembelajaran spesifik (spesific learning). Dikenal 2 bentuk pokok dalam sistem belajar bentuk classical conditioning dan bentuk operant conditioning. ${ }^{21}$ Dalam konsep classical conditioning dikenal 4 aspek utama yaitu unconditioned stimulus (US), unconditioned response (UR), dan conditioned response $(C R)$. Unconditioned stimulus (US) didefinisikan sebagai stimulus apapun yang dapat memproduksi respon (UR) yang tidak dipelajari. CS, didefinisikan sebagai stimulus yang berdasarkan atas asas stimulus berdampingan dengan US, kemudian mampu menimbulkan respon (CR) yang biasanya tidak terjadi pada kondisi normal alami misalnya ejakulasi prematur, ejakulasi retarda, ejakulasi inkompeten dan kesulitan ereksi. Respon yang tidak alami ini akan tetap terjadi selama CS berpasangan atau kadang berpasangan dengan US.

\section{Pemrosesan/koordinasi melalui neuro- transmiter dan reseptor}

Konsep mengenai komunikasi intraseluler saat ini telah berkembang dengan sangat pesat. Penemuan mengenai substansi neuroaktif pada terminal saraf, misalnya berbagai neuropeptida ternyata membuka horison baru dalam pengenalan neurotransmiter. Dogma yang menyatakan bahwa saraf tunggal hanya mempunyai satu macam neurotransmiter saat ini telah tidak dapat dipertahankan lagi. Beberapa macam neurotransmiter ternyata dapat dijumpai pada terminal sinapsis saraf tunggal. Neurotransmiter ini diregulasi secara genetis pada masing-masing saraf. Neurotransmiter ini dilepaskan dari saraf terminal dan akan bereaksi pada sel pasca sinaptik (terutama sel saraf dan sel otot polos). Berbagai contoh neurotransmiter yang telah ditemukan pada berbagai binatang percobaan dan dikenal sebagai regulator sistem saraf perifer maupun pusat adalah sebagai berikut: ${ }^{22}$

a. Sistem kolinergik: Acethilcholine (Ach) 
b. Sistem Amino Acidergik (amino acid transmitters): Gamma-Aminobutyric Acid (GABA); Aspartate; Glutamate; Glycine; Histamine; Taurine.

c. Sistem Monoaminergik (biogenik amine transmitters) : Adrenaline (Epinephrine)

d. Sistem Dopamin dan Noradrenalin yang dikenal juga dengan nama Katekolamin; Serotonin (5 Hydroxytryptamine, atau 5HT); Tryptamine; Oktopamine.

e. Sistem Peptidergik: Angiotensin, Bombesin; Carnosine; Cholecystokinin; Endorphins, Dynorphin; Luteinizing Hormon Releasing Hormone (LHRH); Methionine dan Leucine Enkephalins; Motilin; Neuromedins $(A-C)$; Neuropeptide $Y$; Neurotensin; Oxytocin, Somatostatin; Substance P (SP); Thyroid Releasing Hormone (TRH); Vasoactive Intestinal Peptide (VIP); Vasopressin.

f. Sistem Purinergik: Adenosin; ADP; AMP; ATP

g. Sistem Nitric Oxidergic: Nitric Oxide (NO) yang diproduksi oleh Nitric Oxide Synthase (NOS)

Yang paling dominan di dalam tubuh saat ini adalah sistem nitric oxidergic dengan neurotransmitter NO yang diproduksi oleh NOS.

Lokasi pada jaringan target pada alat genitalia interna sangat menyebar sehingga memerlukan inervasi sistem adrenergik dan non adrenergik, serta komplementer dengan neurotransmiter. Meksipun serabut saraf tipe simpatis dan parasimpatis termasuk dalam sistem kolinergik, tetapi keduanya berbeda dalam reaksinya terhadap neuropeptida dan khususnya NO. ${ }^{23}$ Pada manusia, ganglia yang berada di dekat leher vesika urinaria dan ganglia di daerah posterior serta lateral prosta, memiliki berbagai neurotransmiter, antara lain tyrosine hydroxylase $(\mathrm{TH})$, dopamine beta hydroxylase (D beta $\mathrm{H})$, calcitonin, gene related peptide (CGRP), neuropeptie $Y$ (NPY), somatostatin (SOM), substance $P(\mathrm{SP})$, vasoactive intestinal peptide (VIP) dan nitric oxide (NO) yang dihasilkan oleh nitric oxide synthase (NOS) ${ }^{24,25}$ Ditemukan pula neurotransmiter lain yang dapat berefek sebagai aktivator maupun inhibitor, misalnya: galanin, metenkephalin (m-ENK), arginin vasopressin $(\mathrm{AVP})^{26}$, dan endothelin-1 (ET-1). ${ }^{27}$

\section{Penyampaian respon dari otak ke penis}

Respon yang berupa implus dari otak (sebagian langsung dari nukleus hipotalamus) ditransmisikan ke bawah melalui daerah dorsolateral sumsum tulang belakang ke daerah lumbosakral yang merupakan pusat otonom yang berkaitan dengan proses ereksi. Rangsang kemudian diteruskan ke saraf dalam rongga panggul dan penis (susunan saraf perifer). Impuls rangsang seksual selain dapat menyebabkan ereksi penis juga merangsang sistem otonom saraf lain yang berkaitan dengan refleks kencing dan denyut jantung.

Keutuhan penyampaian saraf rangsang pada fase ini sangatlah tergantung pada keutuhan jaringan saraf (neurologik) yang normal, neurotransmiter yang tersedia yang tidak terganggu, dan tergantung pula pada keutuhan reseptor. Perlu diingat bahwa ketersediaan neurotransmiter misalnya NO sangat tergantung pada NOS sebagai penghasil yang secara langsung tergantung lagi pada hormon testosteron. Dengan demikian tidak dapat dipungkiri bahwa penyampaian rangsang dari otak ke penis juga tergantung pada kadar testosteron, normalitas metabolisme dan kadar obat-obatan yang mempengaruhinya.

\section{Perubahan aliran darah pada penis}

Secara hemodinamik perubahan aliran darah pada penis ini dapat dibagi sebagai berikut: ${ }^{28}$

a. Flaccid phase: Terjadi pada kondisi istirahat dimana otot polos trabekular kontraksi sehingga aliran darah arteri minimal dan aliran darah vena ke luar lebih cepat. Tekanan korpus cavernosum setara dengan tekanan vena yaitu sekitar 4-6 $\mathrm{mmHg}$.

b. Initial filling phase: Stimulasi eferen parasimpatik menyebabkan relaksasi otot polos sehingga aliran arteri dapat me- 
ningkat 5-10 kali. Volume meningkat dan dimulai inisiasi vena karena stretching venula subtunica dengan sedikit perubahan pada tekanan di dalam korpora.

c. Tumescence phase: Volume meningkat dan tekanan dalam korpora juga meningkat. Penutupan vena meningkat seiring dengan kompresi tekanan pada venula subtunika. Aliran arteri mulai berkurang.

d. Full erection phase: Mekanisme venooklusi teraktivasi mengikuti relaksasi otot polos trabekula. Pada saat ini aliran darah arteri minimal, tetapi yang tampak adalah penis menjadi kaku (rigid) Tekanan di dalam korpora kavernosa biasanya setara dengan tekanan arteri yaitu sekitar $90-100 \mathrm{mmHg}$.

e. Rigid erection phase: Tekanan di dalam korpora cavernosa mungkin setara temporer meningkat sampai beberapa ratus $\mathrm{mmHg}$ sebagai akibat kontraksi dari muskulus iskhiakavernosus. Pada kondisi ini aliran darah arteri benar-benar nol.

Perubahan substansi kimia dan aliran darah pada penis sangat tergantung pada keutuhan sirkulasi darah, hormon-hormon, enzim dan bahan endogen dari penis. Jika produksi NO berkurang, tetapi pemecahan NO oleh enzim dihambat maka dengan sendirinya kadar NO akan meningkat. Jika kadar NO meningkat maka akan terjadi relaksasi otot polos pembuluh arteri sehingga terjadi ereksi.

\section{DISFUNGSI EREKSI}

Disfungsi ereksi dapat dedefinisikan sebagai suatu ketidakmampuan untuk ereksi atau mempertahankan ereksi yang cukup untuk melakukan hubungan seksual yang memuaskan, yang menetap atau berulang paling tidak selama 3 bulan berturut-turut. ${ }^{3,5}$

Disfungsi ereksi merupakan istilah yang saat ini sering dipergunakan sebagai pengganti istilah impotensi. Tampaknya, perubahan istilah impotensi menjadi disfungsi ereksi dimaksudkan untuk menekankan pada ketidakmampuan mencapai dan mempertahankan ereksi penis yang cukup untuk suatu hubungan seksual yang me- muaskan., ${ }^{3,29-31}$ Gangguan fungsi ereksi ini sudah sejak lama merupakan penyebab masalah pada pria dan juga wanita pasangannya.

Pada dasarnya disfungsi ereksi merupakan suatu gangguan kesehatan di mana terdapat ketidakmampuan seorang pria untuk ereksi atau mempertahankan ereksi dalam waktu yang cukup untuk mengadakan hubungan seksual yang memuaskan. ${ }^{3}$ Dilihat dari kapan timbulnya disfungsi ereksi dapat dibagi menjadi disfungsi ereksi primer dan sekunder. Disfungsi ereksi yang sekunder, secara praktis dapat dibagi lagi menjadi disfungsi ereksi yang sifatnya sementara dan yang sifatnya permanen. Oleh karena ada yang bersifat sementara, maka definisi dari disfungsi ereksi haruslah tepat.

\section{Penyebab disfungsi ereksi}

Disfungsi ereksi merupakan suatu kelainan dengan penyebab multifaktorial. Berdasarkan penjelasan sebelumnya tentang anatomi, persarafan, dan fisiologis ereksi, dapatlah dimengerti bahwa setiap faktor yang mengganggu mekanisme ereksi yang normal, mulai dari tingkat pusat di hipotalamus dan kelenjar pinealis (sebagai tempat awal penerimaan rangsangan yang berasal dari pikiran/psikis maupun yang berasal dari panca indera) sampai pada organ penis itu sendiri, dapat menimbulkan gangguan pada ereksi penis. Dengan demikian ketidakmampuan seorang pria untuk mencapai atau mempertahankan ereksi dapat merupakan hasil akhir dari berbagai kondisi. Secara garis besar penyebab disfungsi ereksi dapat dibagi dalam dua kelompok utama yaitu organik dan psikogenik. Selain pembagian tersebut ada juga yang membaginya ke dalam tipe vaskulogenik dan nonvaskulogenik. ${ }^{32}$ Tipe vaskulogenik dihubungkan dengan penyebab organik (vaskular) sedangkan tipe non vaskulogenik dikaitkan dengan penyebab psikogenik dan neurogenik. Pada kenyataannya, sampai sekarang dikotomi antara penyebab organik di satu sisi dan penyebab psikogenik dan neurogenik di sisi yang lain sukar dilakukan karena adanya kaitan yang erat di antara kedua kelompok 
penyebab tersebut. Dengan kata lain, disfungsi ereksi akibat faktor organik selalu dikaitkan dengan faktor psikogenik, demikian pula sebaliknya. Keadaan ini dapat dibuktikan dengan adanya kasus-kasus disfungsi ereksi organik yang manifestasinya lebih berat dari pada kenyataan sebenarnya akibat peranan faktor psikogenik yang menyertainya. $^{33}$

\section{Diagnosis disfungsi ereksi}

Dalam Diagnostic and Statiscal Manual of Mental Disorders, edisi keempat (DSM-IV) disfungsi ereksi dikenal dengan istilah "gangguan ereksi laki-laki". Kriteria diagnosisnya adalah sebagai berikut: (A) Ketidakmampuan yang menetap untuk mencapai atau untuk mempertahankan ereksi yang adekuat, sampai selesainya hubungan seksual; (B) Gangguan menyebabkan penderitaan yang jelas atau kesulitan interpersonal; (C) Disfungsi seksual tidak lebih baik diterangkan oleh gangguan aksis I lainnya (kecuali disfungsi seksual lain), dan semata-mata bukan efek fisiologis langsung dari satu zat (misalnya, obat yang disalahgunakan, medikasi) atau sesuatu kondisi medis umum. ${ }^{34}$

Di Indonesia INA-EDACT (Indonesian Erectile Dysfunction Advisory Council and Training) menganjurkan langkah-langkah identifikasi disfungsi ereksi sebagai berikut: (1) Pengenalan masalah awal dan evaluasi awal; (2) Evaluasi fungsi seksual pria dengan menggunakan IIEF-5; (3) Klasifikasi disfungsi ereksi; (4) Riwayat seksual, medis dan psikologis; (5) Pemeriksaan fisik; (6) Pengujian laboratorium; (7) Pendidikan Pasien; (8) Uji diagnostik khusus; dan (9) Indikasi Rujukan. ${ }^{6}$

Untuk menentukan fungsi ereksi dapat digunakan instrumen Erectile Dysfunction Intensity Scale (EDIS). EDIS merupakan suatu instrumen self-rating yang terdiri dari lima pertanyaan dengan lima kemungkinan jawaban pilihan dengan skor satu sampai lima. Skor 5-10; disfungsi ereksi berat; skor 11-15; disfungsi ereksi sedang; skor 16-20; disfungsi ereksi ringan; dan skor 21-25; tidak menderita disfungsi ereksi. ${ }^{3}$

\section{Pengobatan disfungsi ereksi}

Pengobatan disfungsi ereksi seharusnya ditujukan terhadap penyebab dasarnya. Kemudian diberikan pengobatan untuk membantu memperbaiki fungsi ereksi. ${ }^{6,56} \mathrm{~s}$ Berdasarkan rekomendasi yang diberikan oleh International Scientific Committee on The Evaluation and Treatment of Erectile Dysfunction pada $1^{\text {st }}$ International Consultation on Erectile Dysfunction di Paris, Juli 1999 maka pengobatan disfungsi ereksi meliputi empat kelompok; yaitu : (1) Sexual counselling and education; (2) Oral therapy; (3) local therapy, dan (4) surgical therapy. ${ }^{35}$

\section{Sexual counselling and education}

Dalam kelompok terapi ini termasuk sex therapy, psychsexual therapy atau marital therapy. Terapi ini ditujukan bagi individu atau pasangan yang memiliki masalah yang berkaitan dengan faktor interpersonal dan masalah psikologis yang spesifik seperti distres interpersonal, masalah performa seksual, disfungsi dalam pola komunikasi, dan kondisi-kondisi komorbiditas yang mempengaruhi fungsi seksual.

Pada sex therapy perlu diketahui tentang hal-hal berikut: apa yang dialami pasien dan bagaimana hal itu terjadi, apa yang diharapkan oleh pasangannya, bagaimana pemahaman pasangannya, apa yang sudah dilakukan oleh pasangannya untuk mengatasi penderitaannya, serta bagaimana kondisi terakhir. Evaluasi juga dilakukan terhadap hubungan antar pasangan, terutama yang menyangkut komunikasi seksual. Selain itu, adanya masalah seksual dalam diri terapis harus diselesaikan agar tidak menimbulkan hambatan dalam proses terapi. ${ }^{3}$

Keuntungan psychosexual therapy adalah karena bersifat tak invasif dan dapat dipergunakan secara luas. Kerugiannya meliputi variabilitas manfaatnya, beban biaya yang dapat ditanggung oleh pasien atau pasangan, dan ketersediaan terapis yang berkualifikasi.

\section{Oral therapy}

Oral therapy dapat merupakan peng- 
obatan lini pertama bagi sebagian besar pasien oleh karena potensinya yang dapat diandalkan maupun sifatnya yang tak invasif. Pada umumnya terapi oral bekerja secara sentral (seperti agonis dopaminergik), secara sentral dan perifer (seperti penghambat alfa adrenergik), atau cara perifer (seperti inhibitor fosfodiesterase 5 atau prekursor nitric oxide (NO), dan sebagai inducer atau sebagai enhancer.

Obat-obat yang termasuk dalam kelompok ini adalah yohimbine, apomorfin, fentolamin, sildenafil sitrat, melanotan II, dan L-arginine. ${ }^{36,37}$

Keuntungan terapi oral ini ialah karena terapi ini mudah diterima oleh pasien, mudah digunakan, dan relatif bermanfaat. Kerugiannya berkaitan dengan kontraindikasi, harganya yang relatif mahal, dan kurangnya data follow up berkaitan dengan penggunaan jangka panjang.

\section{Local therapy}

Kelompok terapi ini meliputi terapi injeksi intrakavernosum, terapi intrauretral, dan peralatan terapi vakum (vacum device therapy). Terapi ini diindikasi kepada pasien-pasien yang mempunyai kontra indikasi terhadap terapi oral tertentu atau mereka yang mengalami efek sampingan dari terapi oral. Sebagai tambahan, terapi lokal dapat merupakan pilihan terapi pertama berdasarkan pilihan pasien.

Keuntungan dari terapi injeksi penis meliputi manfaatnya yang luas, relatif aman dan onset terapi yang cepat. Kerugiannya meliputi sifat invasif yang berkaitan dengan dengan cara pemberiannya dan harganya yang relatif mahal. Keuntungan dari terapi intrauretral adalah karena sifatnya yang kurang invasif. Kerugiannya berhubungan dengan efek samping lokal maupun sistemik, harganya yang relatif mahal, dan terjadinya iritasi vagina pada pasangan seksualnya. Keuntungan terapi dengan alat vakum adalah karena sifat non farmakologisnya, dapat digunakan sesuai kebutuhan.

\section{Surgical therapy}

Kelompok terapi meliputi pembedah- an vaskular (microvasclar arterial bypass dan venous ligation) dan penile implants (Implantasi prostetis penis). Terapi vaskular harus didahului dengan tes evaluasi khusus dan pembedahannya dilakukan oleh seorang ahli bedah yang berpengalaman.

Keuntungan implantasi protetis penis adalah berkaitan dengan manfaat dan solusi jangka panjangnya. Kerugiannya berhubungan dengan sifatnya yang reversibel, invasif, komplikasi pembedahan dan kegagalan mekanis.

\section{SINDROM DEPRESI}

Sindrom depresi adalah suatu kumpulan gejala psikiatrik yang ditandai dengan penurunan efek, psikomotor, dan proses pikir. Gejala-gejala depresi sering kali sulit dikenali dalam praktek sehari-hari oleh karena keluhan yang ada lebih sering berupa keluhan somatik yang menahun diserta riwayat pengobatan yang beraneka ragam namun hasilnya tetap kurang memuaskan. Sindrom depresi memiliki berbagai gangguan psikiatrik yang terkandung di dalamnya, antara lain gangguan depresif tingkat berulang, episode afektif campuran, distimia dan siklotimia, gangguan depresif berulang, episode depresif, dan gangguan afektif bipolar. Penyebab sindrom depresi dapat bersifat bio psikososial. ${ }^{7-10}$

\section{Diagnosis sindrom depresi}

Pedoman Diagnostik Sindrom Depresi menurut Pedoman Penggolongan Diagnosis Gangguan Jiwa di Indonesia Edisi III menunjukkan bahwa pada semua tingkatan variasi depresi (ringan, sedang dan berat) pasien biasanya menderita suasana perasaan (mood) yang depresif, kehilangan minat dan kegembiraan, dan berkurangnya enersi yang menuju meningkatnya keadaan mudah lelah dan berkurangnya aktivitas. Biasanya ada rasa lelah yang nyata sesudah kerja sedikit saja. Gejala lazim lainnya adalah: (a) konsentrasi dan perhatian berkurang, (b) harga diri dan kepercayaan berkurang, (c) gagasan tentang perasaan bersalah dan tidak berguna, (d) pandangan masa depan suram 
dan pesimistis, (e) gagasan atau perbuatan membahayakan diri atau bunuh diri, (f) tidak terganggu, (g) nafsu makan berkurang. ${ }^{11}$

Pada gangguan depresi lazim ditemukan sindrom somatik yang berupa: hilangnya minat atau kesenangan pada kegiatan yang biasanya dapat dinikmati; tidak adanya reaksi emosional terhadap lingkungan atau peristiwa yang biasanya menyenangkan; terbangun pagi lebih awal 2 jam atau lebih dari pada biasanya; perasaan depresi yang lebih parah pada pagi hari; adanya bukti objektif dari retardasi dan agitasi psikomotor yang nyata (disebutkan atau dilaporkan oleh orang lain); kehilangan nafsu makan secara menyolok; penurunan berat badan; kehilangan libido secara menyolok. ${ }^{8,11}$ Menurut Wright (1991), 40\% pasien depresi yang datang pada terapis sering mengeluhkan keluhan fisik dan psikologis. ${ }^{38}$

Untuk menegakkan diagnosis gangguan (sindrom) depresi dapat dilakukan melalui wawancara psikiatrik berdasarkan pedoman diagnostik menurut PPDGJ-III di atas atau dengan menggunakan instrumen psikometrik seperti Hamilton Rating Scale for Depression (HRSD). ${ }^{12}$

\section{Pengobatan sindrom depresi}

Pengobatan pada sindrom depresi terdiri dari terapi psikososial dan farmakoterapi. Terapi psikososial dapat berupa terapi jangka pendek dan terapi jangka panjang. Terapi jangka pendek dapat berupa terapi kognitif, terapi interpersonal, dan terapi perilaku. Sedangkan psikoterapi berorientasi psikoanalitik merupakan terapi jangka panjang. Apa yang membedakan antara terapi psikososial jangka pendek dari pendekatan yang berorientasi psikoanalitik adalah terletak pada peranan aktif dan sifat direktif (mengarahkan) dari terapis yang sangat menonjol pada terapi jangka pendek. ${ }^{39}$

Berbagai kelompok obat antidepresan yang tersedia saat ini adalah: golongan trisiklik (misalnya amitriptilin, klomipramin), tetrasiklik (misalnya mianserin), penghambat ambilan serotonin-noradrenalin (misalnya venlafaxine), inhibitor monoamin oksi- dase tak reversibel (misalnya phenelzine, tranylcypromine), penghambat monoamin oksidase, anti depresan atipikal seperti penghambat ambilan spesifik serotonin (sertralin, fluvoxamine, fluxetine, paroxetine), aminoketon (bupropion), dan triazolopyridine (Trazodone). Semua antidepresen yang tersedia saat ini memerlukan waktu minimal tiga sampai empat minggu untuk menunjukkan efek terapeutik yang bermakna, walaupun mungkin dapat mulai menunjukkan efeknya lebih awal. ${ }^{39}$

\section{Hubungan sindrom depresi dengan dis- fungsi ereksi}

Sebagaimana diketahui bahwa fungsi seksual yang normal merupakan suatu proses biopsikososial. Dengan demikian, disfungsi ereksi hampir selalu memiliki komponen organik dan psikologi, sehingga gangguan ini membutuhkan evaluasi dan pengobatan yang bersifat multidisiplin. Faktor-faktor seperti usia lanjut, menurunnya kadar testosteron, penyakit fisik, penggunaan obat-obat tertentu dan komorbiditas dengan sindrom depresi dapat mengkontribusi terjadinya disfungsi ereksi dan sindrom depresi cukup tinggi, akan tetapi hubungan kausalnya belum jelas benar, dan lebih sering dianggap bersifat saling mempengaruhi. $^{40}$

Sejak lama telah diketahui bahwa terdapat hubungan antara depresi dan perubahan aktivitas seksual. Berkurangnya libido dan kepuasan dalam hubungan seksual dapat merupakan tanda awal dari sindrom depresi. ${ }^{5,41-43}$

Hasil survei yang diperoleh dari Massachutte Male Aging Study (MMAS) menunjukkan bahwa 1290 responden berusia 40-70 tahun sebanyak 52\% menderita disfungsi ereksi derajat tertentu. Prevalensi ini meningkat dari 5\% pada usia 40 tahun sampai $15 \%$ pada usia 70 tahun. Di Amerika Serikat, jumlah pasien disfungsi ereksi diperkirakan sebanyak 10-20 juta dalam kelompok umur terbanyak pada usia 65 tahun atau lebih. Selanjutnya, pada penelitian ini ditemukan bahwa faktor psikologis, termasuk sindrom depresi berhubung- 
an erat dengan terjadinya disfungsi ereksi. Berkurangnya minat dalam aktivitas seksual pada 50\%-90\% individu dengan sindrom depresi. Pada depresi berat, disfungsi ereksi mungkin ditemukan pada hampir $90 \%$ dari kasus, 59\% pada depresi sedang, dan $25 \%$ pada depresi ringan. ${ }^{44}$ Walaupun di Indonesia belum ada survei yang cukup besar, namun dari gambaran pasien disfungsi ereksi yang datang ke klinik impotensi dapat diperkirakan hasilnya tidak jauh berbeda dengan yang terjadi di belahan dunia lainnya. ${ }^{6}$

Hubungan antara depresi dan disfungsi ereksi telah dikemukakan oleh beberapa penulis. Penelitian Feldman, dkk (1994) dari survei MMAS menemukan adanya korelasi positif antara disfungsi ereksi dan depresi. Pada tingkat atau derajat depresi yang maksimum, hubungan kedua gangguan ini mendekati 90\%. Penelitian Araux Pachecho (1992), menunjukkan korelasi positif antara pasien-pasien yang membutuhkan alat vakum dengan gangguan depresi. Selanjutnya, menurut Ackerman, dkk. (1995) "Konsekuensi psikologis disfungsi ereksi telah benar-benar nyata, dan seringkali meliputi depresi, anxietas dan distres relasional". ${ }^{45}$

\section{KESIMPULAN}

Disfungsi ereksi ialah suatu keadaan di mana ereksi penis tidak dapat dicapai atau dipertahankan untuk melakukan hubungan seksual. Kondisi ini dahulu dikenal dengan istilah impotensi seksual, yang sebenarnya merujuk pada berbagai masalah seksual yang berkaitan dengan gangguan pada libido, gangguan ejakulasi, serta gangguan orgasme.

Fungsi seksual yang normal merupakan suatu proses biopsikososial. Dengan demikian, disfungsi ereksi hampir selalu memiliki komponen organik dan psikologi, sehingga gangguan ini membutuhkan evaluasi dan pengobatan yang bersifat multidisiplin. Faktor-faktor seperti usia lanjut, menurunnya kadar testosteron, penyakit fisik, penggunaan obat-obat tertentu dan komorbiditas dengan sindrom depresi dapat mengkontribusi terjadinya disfungsi ereksi dan sindrom depresi cukup tinggi, akan tetapi hubungan kausalnya belum jelas benar, dan lebih sering dianggap bersifat saling mempengaruhi.

\section{DAFTAR PUSTAKA}

1. Jenck F, Moreau JL, Mutel V, Martin JR, Haefely WE. Evidence for a role of $5-\mathrm{HT}_{\mathrm{IC}}$ receptors in the antiserotonergic properties of some antidepressant drugs. Eur J Pharmacol. 1993; 231: 223-229.

2. Nofzinger EA, Thase ME, Reynolds CF. Sexual function in depressed men. Assessment by self report, behavioural and nocturnal penile tumescence measures before and after treatment with cognitive behaviour therapy. Arch Gen Psychiatry. 1993; 1: 24-30.

3. Pangkahila JA. Disfungsi ereksi. Dalam: Pangkahila W. Editor. Bahagia tanpa gangguan fungsi seksual. Jakarta: Penerbit Kompas, 2001.

4. Sadock VA. Normal human sexuality and sexual dysfunction. Dalam: Sadock, BJ, Sadock VA. editors. Comprehensive Textbook of Psychiatry. $7^{\text {th }}$ Ed. Philadelpha: Lippincott Williams \& Wilkins, 2000; p. 1577-1608.

5. Bonierfale M. Sexual disturbances in 4557 depressed patient: A French Survey. Psych, 2002; 17 (Suppl 1): 208.

6. IDI. Penatalaksanaan disfungsi ereksi. Materi Pendidikan Dokter Berkelanjutan, Jakarta, 1999.

7. Akiskal HS. Mood disorders: introduction and Overview. Dalam: Sadock BJ, Sadock VA, editors. Comprehensive Textbook of Psychiatry. $7^{\text {th }}$ Ed. Philadelphia: Lippincott Williams \& Wilkins, 2000a; p. 1284-97.

8. Akiskal HS. Mood disorders: clinical feature. Dalam: Sadock BJ, Sadock VA, editors. Comprehensive Textbook of Psychiatry. $7^{\text {th }}$ Ed. Philadelphia: Lippincott Williams \& Wilkins, 2000b; p. 1338-76.

9. Kelsoe JR. Mood disorders: genetics. Dalam: Sadock BJ, Sadock VA, editors. Comprehensive Textbook of Psychiatry. $7^{\text {th }}$ Ed. Philadelphia: Lippincott Williams\&Wilkins, 2000; p. 2482-91.

10. Gabbard GO. Mood disorders: psychodynamic aspects. Dalam: Sadock, BJ, Sadock VA, editors. Comprehensive 
Textbook of Psychiatry. $7^{\text {th }}$ Ed. Philadelphia: Lippincot Williams \& Wilkins, 2000; p. $1328-1337$.

11. Depkes RI. Pedoman penggolongan dan diagnosis gangguan jiwa di Indonesia. Edisi 3. Jakarta: Departemen Kesehatan RI, 1992.

12. Blacker D. Psychiatric rating scales. Dalam: Sadock BJ, Sadock VA, editors. Comprehensive Textbook of Psychiatry. $7^{\text {th }}$ Ed. Philadelphia: Lippincott Williams \& Wilkins, 2000; p. 755-782.

13. Jordan GH. Erectile function and dysfunction: how it works and what can be done when it doesn't. Postgard Med. [homepage on the internet] Februari 1999; 105(2). [cited 2004 Jun, 3], Available From: URL: http://www./postgraduateMedicine/ErectileFunctionAndysfunctio n.htm

14. de Groat WC, Steers WD. Neuroanatomy and neurophysiology of penis erection. Dalam: Tanagho EA, Lue TF, McClure $\mathrm{RD}$, editors. Contemporary Management of Impotency and Infertility. Philadelphia: Williams \& Wilkins, 1998; p. 3-27.

15. Eardley I, Sethia K. Erectile dysfunction. Current Investigation and Managemen. I. Introduction. New York: Mosby Int Ltd, 1998; p. 1-4.

16. Van Driel MF. Erectile dysfunction, diagnosis and treatment. Proefschrift. Groningen: Rijks Universiteit Groningen; 1991.

17. Marieb EN. Anatomy and physiology. California: The Benyamin/Summing Pub Co; 1989.

18. Corola R, Harley JP, Noback CR. Human anatomy and physiology. The Autonomic Nervous System. New York: McGraw-Hill Inc, 1990.

19. Stefanick ML. The cicardian pattern of spontaneous seminal emission, sexual activity and penile reflexes in the rat. Physiol Behav. 1983; 31(6): 737 - 743.

20. Mantini F, Ober WC, Carrison CW, Welch K. Fundamental of anatomy and physiology. Toront: Prentice-Hall Inc, 1992.

21. Kockott G. Behaviour therapy of psychogenic sexual dysfunction in men. Dalam: Hafez ESE, Editor. Human Semen and Fertility Regulation in Men. Saint Louis: The CV Mosby Co, 1976; p. 513-24.
22. Bradford HF. Chemical neurobiology. New York: WH Freeman; 1986.

23. Dail WG. Autonomic innervation of male reproductive genitalia. Dalam: Maggi, CA, editor. Nervous Control of the Urogenital System. Chur, Switzerland: Harwood Academic Pub, 1993; p. 69-101.

24. Jen PY, Dixon JS, Gosling JA. Colocation of tyrosine hydroxylase, nitric oxide synthase and neuropeptides in neurons of the human postnatal male pelvic ganglia. J Auton Nerv Syst. 1996; 59(1-2): 41-50.

25. Laumann EO, Park A, Rosen RC. Sexual dysfunction in the US: prevalence and predictors. JAMA, 1999; 281: 537-544.

26. Andersson KE, Fovaeus M, Hedlund H, Holmquist F, Lundin S. Immunoreactive arginin vaspressin (AVI) and effects of AVP in the human vas deferens. J Urol. 1988; 140: 1054-1057.

27. Luciano LG, D'Orleans-Juste P, Calixto JB, Rae GA. Endothelin-I selectively protentiates the purinergic component of sympathetic neurotransmission in rat seminal vesicle. J Cardiovasc Pharmacol. 1998; 31 (Suppl 1): SS 15-17.

28. Rosen RC, Ashton AK. Prosexual drugs: empirical status of the new aphrodisiacs. Arch Sex Behav. 1993;22: 521-543.

29. Kaplan HS. The new sex therapy. First Edition. London: Bailliere \& Tindal; 1994.

30. Hyde JS. Understanding human sexuality; Fifth Edition. New York: McGraw-Hill Inc; 1994.

31. Benet AE, Melman A. The epidemiology of erectile dysfunction. Urologic Clinic of North America. 1995; 22: 699-709.

32. Pryor JP, Dickinson IK. Special investigation. Dalam: Gregoir A, Pryor JP, editors. Impotence-An Integrated Approach to Clinical Practice; $1^{\text {st }}$ Ed. United Kingdom: Churchill Livingstone, 1993; p.115-126.

33. Brancroft J, Wu FC. Erectile impotence. British Medical Journal. 1985; 290: 566568.

34. Sadock VA. Normal human sexuality and sexual dysfunction. Dalam: Sadock BJ, Sadock VA, editors. Comprehensive Textbook of Psychiatry. $7^{\text {th }}$ Ed. Philadelphia: Lippincott Williams \& Wilkins, 2000; p. 1577-1608.

35. Jardin A, Wagner G, Khoury S, Giuliano F, Padma-Nathan H, Rosen R. Erectile 
dysfunction. Recommenda-tion of the International Scientific Committee on the: Evaluation and treatment of Sexual Dysfunction. $\quad 1^{\text {st }}$ International Consultation on Erectile Dysfunction. Paris, 1-3 July 1999.

36. Saenz de Tejada I, Ware JC, Blanco R, Pittard JT, Nadig PW, Azadzoi KM et al. Pathophysiology of prolonged penile erection associated with trazodone use. $\mathrm{J}$ Urol. 1991; 145: 60-64.

37. Kurt U, Ozkardes H, Altug U, Germiyanoglu C, Gurdal M, Erol D. The efficacy of anti serotonergic agents in the treatment of erectile dysfunction. $\mathbf{J}$ Urol. 1994; 152: 407.

38. Waden TA, Stuncard AJ. Psychological consequences of obesity. Dalam: Waden TA, Stuncard AJ, editors. ObesityTheory and Therapy, $2^{\text {nd }}$ Ed. New York: Raaven Press, 1993; p. 163-78.

39. Rush JA. Mood disorders: treatment of depression. Dalam: Sadock BJ, Sadock VA, editors. Comprehensive Textbook of Psychiatry. $7^{\text {th }}$ ED. Philadelphia: Lippincott Williams \& Wilkins, 2000; p. $1373-85$.

40. Seidman SN, Roose SP. The relationship between depression and erectile dysfunction. [homepage on the internet] 2001. [cited 2004 Jun. 5]. Available from: URL: http://www.ncbi.nlm. nih.gov/entrez/query.fcgi?cmd=REtrieve $\& \mathrm{db}=$ Pubmed $\&$ list_uids $=11122956 \&$ do $\mathrm{pt}=$ Abstract\&itool=iconabstr.

41. Priest RG. Impotence. Dalam: Priest RG, Editor. Psychiatry in Medical Practice. $1^{\text {st }}$ Ed. Great Britian: McDonald \& Evans, 1982; p. 142-54.

42. Cole M. Physiologica approaches to treatment. Dalam: Gregoire A, Pryor JP, editors. Impotence. An Integrated to Clinical Practise. $1^{\text {st }}$ ed. United Kingdom: Churchill Livingstone, 1993; p.129-64.

43. WHO. Sexual dysfunction. Dalam: WHO. Management of Mental Disorder. $2^{\text {nd }}$ Ed. Sydney: WHO Collaborating Center for Mental Health and Substance Abuse, 1997; p. 554-89.

44. Feldman HA, Goldstein I, Hatzichristou DG, Krane RJ, McKinlay JB. Impotence and its medical and psychosocial correlates: result of the Massachusetts male aging study. J Urol. 1994; 151: 5461.

45. Initili H, Nier D. Self esteem and depression in men who present with erectile dysfunction. [homepage on the internet] 2003. [cited 2003 Jun.5], Available from: URL: http://www.duj. com/NIer.html.accessed, June 52003. 